\title{
Factor Analysis Related to Truck Mixer Driver Work Accident at PT Bosowa Beton Indonesia
}

\author{
Antonius Budi Trianto', Muh. Yusuf ${ }^{2}$, Muh. Rifai $^{3}$ \\ ${ }^{1,2,3}$ Department of Magister Public Heath, High School of Health Sciences Tamalatea, Makassar, Indonesia
}

Corresponding Author: Antonius Budi Trianto

\begin{abstract}
Background: Accidents due to work are something that is very difficult for workers to avoid, such as workers, factory employees, truck drivers and other field workers, so that they require more attention from the government, private sector and other employers as well as from the workers themselves. Most commonly we often encounter on the road which causes many casualties. This study aims to determine the factors that cause work accidents on mixer truck drivers at PT Bosowa Beton.
\end{abstract}

Methods: This research uses quantitative methods with an analytical approach and a cross sectional study design, with a sample of 60 drivers.

Research Result: The variables related to the work accident of the mixer truck driver at PT Bosowa Beton are road conditions $(\mathrm{p}=0.000<$ $=0.05)$ and the work fatigue variable $(\mathrm{p}=0.009$ $<=0.05)$, as well as the variable working time with value $(\mathrm{p}=0.04<=0.05)$ while for variables that are not related to work accidents are vehicle conditions $(\mathrm{p}=0.355)$, ergonomics $(\mathrm{p}=0.474)$ and smoking $(\mathrm{p}=1,000)$.

Conclusion: The most dominant cause of work accidents is work fatigue, it is recommended for companies to conduct periodic testing and evaluation of workforce performance to improve work quality and detect early indications of fatigue.

Keywords: Work accident and mixer truck driver

\section{INTRODUCTION}

Occupational safety and health is one of the important elements for workers, where every worker has the right in terms of protection, especially in the field of occupational safety and health, morals and decency, and get proper treatment. For this reason, the implementation of health efforts is very necessary to protect the health of workers and increase work productivity. Work-related accidents are something that is very difficult to be avoided by workers, such as workers, factory employees, truck drivers and other field workers, thus requiring more attention from the government, private sector and other employers as well as from the workers themselves, accidents are one of the most common hazards we often encounter on the road which causes many fatalities. The World Health Organization has conducted research that predicts road accidents will be the fifth leading cause of death by 2030 . Many of these accidents will involve trucks. It has been determined that in large part this is due to several factors namely: Failure to adjust speed for various road conditions, New area the driver is travelling in, Fatigue due to not getting enough rest, Illegal driving maneuvers, Distraction (cigarettes); Use of illegal drugs; The influence of alcohol; Inadequate observation of the environment and traffic conditions; Inadequate mechanical maintenance (especially brakes and tires); Unsafe weather conditions such as fog, ice, snow, flooding; Road conditions such as dangerous and winding roads as well as unmaintained roads and heavy traffic areas; Lack of professional training and licensing of truck drivers. [1]. 
Worldwide, millions of truck-related accidents are reported, of which $68 \%$ of fatal truck-related accidents occur in rural areas, on interstate roads and highways. During 2017, 4,889 large trucks had accidents which also resulted in fatalities [2].

Several studies worldwide recorded that heavy truck and tractor-trailer drivers suffered 745 fatal injuries, of all types of accidents, according to newly released data from the Census of Fatal Occupational Injuries (CFOI) conducted by the US Bureau of Labor Statistics, overall., A total of 4,836 fatal work accidents were recorded in the United States in 2015, an increase from the 4,821 fatal injuries reported in 2014. The number of fatal occupational accidents involving transportation incidents, the incidents that cause the most fatal occupational injuries, increased in 2015, where incidents in highways rose $9 \%$ in 2015 to 1,264 and accounted for $26 \%$ of all fatal occupational accidents. Nearly half of these deaths involved medium trucks, tractor-trailers, or pickup trucks[3].

In Indonesia in 2018 the number of work accidents was still quite high, where the Social Security Administration Agency (BPJS) for Manpower recorded 157,313 cases, or 40,273 cases every day, and 4,678 cases $(2.97 \%)$ resulted in disability, and $2,575(1,64 \%)$ cases ended in death. The data shows, every day 12 BPJS Employment participants experience disability, and seven participants die, of the 157,313 work accidents, $35 \%$ or around 55,059 people experience work accidents due to fatigue, and $65 \%$ or around 102,253 people experience accidents. Work caused by other factors, such as Occupational Diseases, Human Errors, and Work Pressure. This was stated by the President Director of BPJS Employment, Agus Susanto, in the socialization of work and driving safety. (Yusuf M. BPJS Employment Data, 40,273 Work Accident Cases Happen Every Day [4].

The results of a study conducted in Makassar City by Maria Ulva, (2019) showed that in 2017 there were 26.59\% accident cases, the majority of which were in vehicles. motorcycles by $62.76 \%$ with the highest accident impact in the form of minor injuries by $96.1 \%$. Types of double accidents by $82.14 \%$ where the average accident occurred at 13.00-16.00 at $19.33 \%$. Humans are $97.14 \%$, the results of other studies show that driving behavior at high speed causes 156 accidents and disorderly causes 4803 accidents. Vehicle factors cause $0.83 \%$ of accidents. Environmental factors cause accidents by $2.04 \%$, infrastructure conditions in the form of roads straight by $79.05 \%$, sharp bend by $49.15 \%$ and weather conditions by $0.07 \%$ [5]

Car Mixer truck is a means of transporting concrete from the batching plant to the project site which complete with a mixer in the form of a knife in the drum. The benefit of using heavy equipment Truck Mixer is to make it easier for humans to do their work, so that the expected results can be achieved more easily in a relatively shorter time. The function of this tool is used to mix rock, cement, and water into a desired shape and size. The carrying capacity per truck for one way is $7 \mathrm{~m}^{3}$. Based on preliminary data obtained from PT Bosowa Beton Indonesia, there were 70 mixer truck drivers who are still actively working, it is known that in the last 3 years there have been 10 cases of work accidents in mixer truck drivers caused by several factors, such as environment, behavior, driver characteristics., as well as because the vehicle is no longer feasible.

The impact of a work accident that occurs on the driver of a company in addition to being directly detrimental to the driver and other people who are victims, also has a serious impact on the company, namely the increase in the cost of health compensation, damage to the mixer truck, cessation of work time or even the loss of a driver who quality if it causes death or the inability to work again.

Based on the description of the problems described above, the researchers are interested in conducting research on the 
factors that cause driving accidents in mixer truck drivers at PT Bosowa Beton Indonesia.

\section{RESEARCH METHODS}

This research is a quantitative research, "Quantitative research method can be defined as a research method based on the philosophy of positivism, used to research on a particular population or sample, analytical research approach, cross sectional study design to link the independent and dependent variables [6].

\section{RESEARCH RESULT}

This research was carried out for approximately three months at PT Bosowa Beton Indonesia with a sample of 60 people, while the results of this study are presented in tabular form accompanied by narration, starting from univariate, bivariate analysis,

Table 1: Distribution of respondents based on respondent
\begin{tabular}{|l|c|c|}
\hline \multicolumn{1}{|c|}{ Characteristics } & Total & Percent \\
\hline Age & 14 & 23.33 \\
\hline$\leq 30$ years & 36 & 60.00 \\
\hline $31-40$ years & 10 & 16.67 \\
\hline$>40$ years \\
\hline Working period & 15 & 25.00 \\
\hline < 5 years & 45 & 75.00 \\
\hline$\geq 5$ years &
\end{tabular}

Based on the age criteria, it shows that the age group of respondents is mostly $31-40$ years old, which is $60 \%$, then the $<30$ years old group is $23.3 \%$ and the age group > 40 is $16.67 \%$. Table 1 above shows that $75 \%$ of the 60 respondents have worked $>5$ years and only $25 \%$ have worked $<5$ years.

Table 2: The relationship between the independent variable and the dependent variable

\begin{tabular}{|c|c|c|c|c|c|c|c|}
\hline \multirow[t]{3}{*}{ Variable } & \multicolumn{6}{|c|}{ Work Accident } & \multirow[t]{3}{*}{$\mathbf{p}$} \\
\hline & \multicolumn{2}{|c|}{ Ever } & \multicolumn{2}{|c|}{ Never } & \multicolumn{2}{|c|}{ Total } & \\
\hline & $\mathbf{n}$ & $\%$ & $\mathbf{n}$ & $\%$ & $\mathbf{n}$ & $\%$ & \\
\hline \multicolumn{7}{|l|}{ Road condition } & 0.000 \\
\hline Poor & 23 & 82.14 & 5 & 17.86 & 28 & 100 & \\
\hline Good & 8 & 25 & 24 & 75 & 32 & 100 & \\
\hline \multicolumn{7}{|l|}{ Work fatigue } & 0.009 \\
\hline Very tired & 15 & 79.9 & 4 & 21.1 & 19 & 100 & \\
\hline Tired & 11 & 45.8 & 13 & 54.2 & 24 & 100 & \\
\hline Less & 5 & 29.4 & 12 & 70.6 & 17 & 100 & \\
\hline \multicolumn{7}{|c|}{ Vehicle condition } & 0.355 \\
\hline Not good & 4 & 80 & 1 & 20 & 5 & 100 & \\
\hline Good & 27 & 49.1 & 28 & 50.9 & 55 & 100 & \\
\hline \multicolumn{7}{|l|}{ Ergonomics } & 0.474 \\
\hline Poor & 6 & 66.67 & 3 & 33.33 & 9 & 100 & \\
\hline Good & 25 & 49.02 & 26 & 50.98 & 51 & 100 & \\
\hline \multicolumn{7}{|l|}{ Working time } & 0.040 \\
\hline Risk & 9 & 36.00 & 16 & 64.00 & 25 & 100 & \\
\hline No risk & 22 & 62.86 & 13 & 37.14 & 35 & 100 & \\
\hline \multicolumn{7}{|l|}{ Smoking } & 1,000 \\
\hline Yes & 28 & 51.85 & 26 & 48.15 & 54 & 100 & \\
\hline No & 3 & 50 & 3 & 50 & 6 & 100 & \\
\hline
\end{tabular}

Table 2 above shows that there are 28 respondents who answered that the road conditions were not good, where $82.14 \%$ of them answered that they had experienced an accident caused by poor road conditions and there were $17.86 \%$ who did not have an accident. Of the 32 respondents who answered the road conditions were good, there were $25 \%$ who had an accident and as many as $75 \%$ who did not have an accident. The results of the statistical test value of $\mathrm{p}=$ 0.000 , where this value is smaller than yang $=0.05$ which means that $\mathrm{Ha}$ is accepted and it is concluded that there is a relationship or road condition is one of the factors causing work accidents on the driver

Table 2 above also shows that there are 19 respondents who experience work fatigue in the very tired category, where $79.9 \%$ of them answered that they had experienced an accident and there were $21.1 \%$ who did not have an accident. In addition, of the 24 respondents who are included in the tired category, $45.8 \%$ have experienced work accidents and $54.2 \%$ have not experienced work accidents. And of the 
17 drivers who fall into the category of less work fatigue, there are $29.4 \%$ who have had an accident and as many as $70.6 \%$ who have not had an accident. The test results show that the value of $p=0.009$, where this value is smaller than $=0.05$ which means that $\mathrm{Ha}$ is accepted and it is concluded that there is a relationship or work fatigue is one of the factors causing work accidents on the driver.

Table 2 above shows that there are 5 respondents who have poor vehicle conditions, where $80 \%$ of them answered that they had experienced an accident and there were $20 \%$ who did not have an accident. Of the 55 respondents who answered that they had a good vehicle condition, $49.1 \%$ had experienced an accident and $50.9 \%$ had not had an accident. The statistical test results show that the value of $p=0.355$, where this value is greater than $=0.05$ which means that $\mathrm{Ha}$ is rejected and it is concluded that there is no relationship or the condition of the vehicle is not a factor causing work accidents in drivers.

Based on ergonomic variables, table 2 below above shows that there are 9 respondents who answered that ergonomically it was not good, where $66.67 \%$ of them answered that they had experienced an accident and there were $33.33 \%$ who did not have an accident, of the 51 respondents who answered ergonomiccally well there were $49.02 \%$ who had experienced an accident, accidents and as many as $50.98 \%$ who did not have accidents. The statistical test results show that the value of $p=0.474$, where this value is greater than $=0.05$ which means that $\mathrm{Ha}$ is rejected and it is concluded that there is no relationship or work ergonomics is not a factor causing work accidents.

Based on the working time variable, it shows that there are 25 respondents who answered risky working time, where $36 \%$ of them answered that they had experienced an accident and there were $64 \%$ who answered that they did not have an accident.
Of the 35 respondents who answered that their working hours were good or not at risk, there were $62.86 \%$ who had an accident and $37.14 \%$ who did not have an accident.

The results of statistical tests using Chi-square show that the value of $p=0.04$, where this value is smaller than $=0.05$, which means that $\mathrm{Ha}$ is accepted and it is concluded that there is a relationship or working time is a factor causing work accidents to drivers.

The smoking variable in table 2 above shows that there are 54 respondents who answered smoking, where $51.85 \%$ of them answered that they had experienced an accident and there were $48.15 \%$ who answered that they did not have an accident.

Of the 6 respondents who answered smoking there were $50 \%$ who had an accident and $50 \%$ who did not have an accident.

The results of the statistical test show that the value of $p=1,000$, where this value is greater than $=0.05$, which means that $\mathrm{Ha}$ is rejected and it is concluded that there is no relationship or smoking condition is not a factor causing work accidents at PT Bosowa Beton Indonesia Makassar drivers.

\section{DISCUSSION}

The results of this study were conducted by interviewing as many as 60 drivers of PT Bosowa Beton Indonesia Makassar $51.7 \%$ of them had experienced work accidents and the remaining $48.3 \%$ had never had a work accident, this study aims to determine the factors that cause work accidents in drivers in terms of aspects of road conditions, work fatigue, working time, ergonomics and driver smoking behavior, of the five variables studied there are two variables that cause driver work accidents at PT Bosowa Beton Indonesia Makassar, namely road conditions and driver work fatigue which will be explained in detail as follows: The following: 


\section{Road Conditions}

The results showed that there were 28 respondents who answered that the road conditions were good, of which 23 respondents answered that they had experienced accidents caused by poor road conditions, the average number of accidents that occurred to drivers on the highway was more during the rainy season, rain $\mathrm{n}$ arrived, this condition is certainly beyond the control or control of the driver so that the potential for accidents that occur is quite large coupled with a fairly heavy and large load.

Accidents that occur can not be separated from the severity of road conditions, this can be seen from the results of the study which showed that as many as 5 respondents did not experience accidents even though the road conditions were damaged, besides that the experience factor of the driver was also one of the supporting factors so that it was quite high, who did not have an accident at work. Based on the travel route through the PT Bosowa Concrete mixer truck, where in Barru district is an area with very difficult road conditions for drivers to take, because it has unsupportive soil characteristics such as still muddy, clay that has not hardened so that cars with heavy loads heavy experience difficulties and of course cause work fatigue on the mixer truck driver, even the dismantling process sometimes takes all day.

In this study also found the fact that the work location of the mixer truck driver PT. Bosowa Beton is damaged a lot and has not been repaired, so that if this condition continues, it will have the potential to cause accidents, in addition to the terrain the mixer truck driver passes uphill and many derivatives so that it has the potential to cause the driver to be hampered on duty.

The weather factor is also one of the triggers so that many mixer truck drivers have accidents as in the results of this study which reveals that drivers who have accidents due to extreme weather such as rain and fog.
The results of the research on road condition variables can be concluded that there is a relationship or road condition is one of the factors causing work accidents at PT Bosowa Beton Indonesia Makassar drivers, the results of this study are in line with research conducted by Windy where road conditions have a significant relationship with the potential for work accidents on truck drivers at PT Berkat Nugraha SinarLestari (Windy et al., 2020), besides that, ekawati in her research also revealed the fact that road conditions while driving caused an increasing number of accidents, especially drivers who drive at high speeds above $60 \mathrm{~km} /$ hour[7 ].

Work accidents are scientifically proven to be one of the factors that cause road accidents, then supported by human factors or drivers who drive vehicles at high speed, where they ignore the safety of themselves, others and of course harm the company because they have to incur additional costs. underestimate the work because they are used to going through the lane, as well as the desire to quickly complete the work so that poor road conditions are ruled out.

Weather is also one of the causes of road conditions to be difficult to avoid causing work accidents, this condition often occurs when it rains heavily, so the road becomes slippery, this condition allows single accidents, even accidents caused by other drivers that are difficult to avoid. . Visibility factor is also one of the conditions that trigger road accidents, where there are conditions where drivers have difficulty seeing damaged roads and cause accidents.

\section{Vehicle Condition}

Results of the study revealed that the condition of the vehicle is not a factor causing accidents to drivers at PT Bosowa Beton, this is because the company periodically conducts routine inspections and services on vehicles.

Several studies have revealed, such as research conducted by Maria Ulva, 2018 that the condition of the vehicle greatly 
affects the driver's accident, such as tire slip, brake failure, tire burst, and the vehicle light factor that is not bright enough to cause the driver's visibility to be disturbed.

It is undeniable that the condition of the vehicle is very important in order to maintain driver safety and increase company productivity, the high number of road accidents cannot be separated from one of the factors of vehicle condition plus bad road conditions, but the most common thing is tire bursts, this condition Of course not only endanger yourself but also endanger other motorists.

The company has made various efforts to improve the quality of employees' work, including drivers and vehicles, where they have a very important role for the company, such as providing regular briefings to all employees every week related to occupational health and safety. This weekly activity is carried out by the company's occupational health and safety party as well as evaluating the performance and findings related to Occupational Health And Safety issues in the company.

In this study it was also revealed that there are still drivers who are lazy to check or carry out maintenance on vehicles before they use trucks, due to work time that will be wasted if they have to carry out maintenance or checking vehicles, besides that truck drivers also often take it lightly if there are problems, minor problems with the vehicle, if this condition continues it can trigger the vehicle to become increasingly severe in severity.

The supervisory role in the company must be observant and more thorough in monitoring the condition of the mixer truck vehicle, so that early prevention can be improved and have an impact on driver productivity and company productivity.

\section{Work fatigue}

Work fatigue is a person's natural feeling of tiredness accompanied by a decrease in willingness, ability to do activities, where this work fatigue can be caused by excessive workloads, as experienced by drivers at PT. Bosowa Beton who experienced a decrease in concentration in driving due to a workload that was too heavy, such as travelling long enough to get out of town and even across provinces. A high enough target becomes a trigger so that the driver allocates their energy at work.

Work fatigue experienced by workers is also a trigger for decreasing motivation and enthusiasm at work, this condition if allowed to continue to drag on can cause work accidents, so that it has the potential to harm the company.

Work fatigue experienced by workers is unavoidable considering that they have to work regardless of time, because of the targets assigned to them, rest periods become irregular, where they must be ready in any condition and situation.

Driver health also needs attention, because driving in conditions that are not fit can cause the driver's physical and psychological condition to become unstable and the potential to cause accidents is also greater, such as a study conducted by Verawati 2020, which found that employee work fatigue was caused by shifts work and working hours that are not appropriate so that it has the potential to cause work accidents and reduce the level of company productivity [8].

Fatigue at work is also known as physiological fatigue caused by the physical environment such as temperature, vibration, noise and lighting. This condition is experienced by many drivers at PT Bosowa Concrete, where it is known that the vehicle being carried is a vehicle with a very large noise level compared to other vehicles; the vibrations that are owned are also very loud coupled with unfavorable road conditions at night with low light levels can cause even more severe fatigue.

The condition of the body that is not ideal due to work fatigue causes the driver to find it difficult to think, decrease concentration, be slow at work will further increase the potential for work accidents, so time management is needed for workers so 
that they are able to work proportionally and remain productive.

\section{Ergonomics}

The research results reveal that ergonomics is not the cause of work accidents for drivers at PT. Bosowa Beton, although some accidents happen to drivers due to the ergonomics of the drivers.

Work accidents can be caused by a condition that is not ideal for the driver, such as an unergonomic position because he sits in a monotonous position and rarely rests and the condition of the seat is no longer suitable for use. This is what triggers the condition of the body in a state that is not ideal in driving and has the potential to cause accidents even though the chances are small as the results of research conducted where only $15 \%$ consider the driving conditions to be not ergonomic.

Kumroni, et al 2018 in their research revealed that for an ideal or ergonomic condition the driver's seat must be made as comfortable as possible both in terms of material and size [9].

In this study also found the fact that in order to avoid muscle fatigue, the driver performs muscle relaxation every 4 hours of travel, such as eating breaks, praying, and others, so as to minimize the occurrence of accidents caused by ergonomic factors.

The results of this study also reveal that low back pain is one of the effects that often arises due to driving for a long time and is too forced, this condition is triggered by the target from the company that must be pursued plus the driver factor who is lazy to stop to rest to stretch the muscles.

The body condition for driving that can be tolerated is 4 hours, which if it exceeds it can cause muscle pain, the results of this study are in line with research conducted by Miriam which revealed that as many as $42.5 \%$ of drivers who drove more than 4 hours without rest experienced muscle pain. This condition of course will affect the condition of the body and have the potential to cause accidents even though the potential is small, such as the results of this study which revealed that ergonomics was not the cause of accidents for drivers at PT. Bosowa Concrete.

\section{Working time}

time in this study has a relationship with the occurrence of work accidents on drivers at PT. Bosowa Beton, where as many as $41.7 \%$ of drivers consider that their working time is in the risky category, because there are several drivers who have to transport until midnight due to an accident or situation that causes the vehicle to have a tire slip on a muddy road, this incident is more happened in Barru district, this condition of course causes the working time taken longer and more risky, some even spend the night on the road.

The working time at $\mathrm{Pt}$. Bosowa Beton actually also depends on the project being worked on at the moment, which is currently working on a railroad project, where the target has been determined and must be completed as soon as possible, this condition triggers, so the mixer truck driver's working time become erratic, some only work 3-4 hours a day, some work until midnight. Road conditions and weather conditions also greatly affect the driver's working time, especially if he has to pass through a traffic jam like the city of Makassar.

Seeing the existing conditions, the company also has limitations in managing working time for mixer truck drivers; there are even truck drivers who have to stay in the car because the working time has exceeded the limits of the truck driver's physical and psychological abilities.

The results of this study are in line with research conducted by Szostak 2019 which revealed people who were injured in work accidents in the Polish construction industry; the parameters tested affect the number of accidents, the number of days worked in a week does not affect the occurrence of work accidents, although there is a slightly increasing trend in the number of accidents in the second half of the week [10]. 
Ideally a person's working time is 68 hours a day and the rest is used for friends and family, rest and society. Porting energy beyond the set working hours will also affect a person's productivity and cause work fatigue, this condition is experienced by many drivers at PT. Bosowa concrete that imposes itself or is "forced" to carry out activities outside of ideal conditions.

The actual working time of the driver is not determined by working hours, but is determined by how many routes are completed, in the city of Makassar, of course it will provide a long working time, because of the congested road conditions, this condition causes the driver to have minimal rest time, this is Of course it must get attention from the company because lack of rest time can cause the driver's condition to be not prime and the potential to cause accidents and disrupt company productivity, even though it has been regulated in Traffic Law no. 22 of 2009 article 90 paragraph 3 which explains that drivers who drive their vehicles for 4 consecutive hours are required to rest for at least half an hour, but this condition is sometimes ignored by drivers because they always feel capable of overcoming it.

\section{Smoking}

The results of this study reveal that smoking activity is not the cause of work accidents for drivers at PT Bosowa Beton, where $90 \%$ of drivers are active smokers and only $10 \%$ of those who do not smoke.

It is undeniable that most truck drivers are smokers and cannot be banned by the company. Truck drivers think that by smoking they can relieve drowsiness while driving; in addition they are more enthusiastic about driving when smoking. However, in this study, no significant relationship was found between smoking activity and the incidence of accidents in the mixer truck driver PT. Bosowa Concrete.

It is still rare to find research related to smoking as a cause of accidents for drivers, where they always argue that smoking can increase their concentration in driving, even though it has been regulated in Law No. driving while smoking, but there are still many of the drivers who do not know, there are those who know but ignore it on the grounds of not being caught and increasing concentration.

Smoking behavior while driving is indeed very disturbing because the ash and smoke emitted can get into the eyes of the driver and other people in the car or behind it, such as motorcycle riders.

All potential causes of accidents should be minimized because it will harm themselves and the company, but there is an assumption that they have been driving while smoking for decades and nothing has happened to them. This condition is the duty of occupational health and safety to continue educating by reminding every week when giving directions. Although in this study smoking while driving has no relationship, anticipatory steps need to be taken, as well as a form of obedience to the applicable rules.

\section{CONCLUSION}

The variable that is the cause of accidents is the condition of roads and work fatigue and excessive working time driver in the PT Bosowa Concrete while the variable that is not related to workplace accidents is the condition of the vehicle, ergonomics, and the activities of smoke.

\section{Acknowledgement: None}

\section{Conflict of Interest: None}

\section{Source of Funding: None}

\section{REFERENCES}

1. World Health Organization, 2018. Road Traffic Injuries. World Health Organization.

2. Ornelas and serna, 2020. Truck Accident Statistics. https://osernalaw.com /truckaccidents/2020-truck-accidentstatistics/. Statistica

3. Johnes, $\mathrm{K}$ Trucking jobs surge to record high. https://www.fleetowner.com/resourcecenter/driver-management/article/ 
21694976/trucking-jobs-surge-to-recordhigh?utm_campaign=Daily+Logistics+New sletter\&utm_source=hs_email\&utm_mediu $\mathrm{m}=$ email\&_hsenc=p2ANqtz-_jVY531G5 kUDLCaHELogd0GmBVb_KecOTIF2xQJ bcJHKn6ZcJrw_mDB4k_oBLICVjRUEkI

4. Tribunnews [Internet]. 2021; https://wartakota.tribunnews.com/2021/01/2 8/ data-bpjsketenagakerjaansetiap-hariterjadi-40273-kasuskecelakaan -kerja).

5. Ulva, M. (2019). Gambaran Karakteristik Kecelakaan Lalulintas Di Kota Makassar Tahun 2014-2018 (pp. 1-165).

6. Sugiyono. (2017). Metode Penelitian Kuantitatif, Kualitatif, R \& D. Bandung: CV Alfabeta

7. Meirinda, D. E., Suroto, \& Ekawati. (2017). Faktor-Faktor Yang Berhubungan Dengan Kecelakaan Lalu Lintas Pada Karyawan Pengendara Sepeda Motor Di Koperasi Simpan Pinjam (Ksp) Sumber Rejeki Blora Devi. Jurnal Kesehatan Masyarakat, 5(3), 240-248.

8. Verawati, L. (2017). Hubungan Tingkat Kelelahan Subjektif Dengan Produktivitas Pada Tenaga Kerja Bagian Pengemasan Di $\mathrm{Cv}$ Sumber Barokah. The Indonesian
Journal of Occupational Safety and Health, 5(1), 51. https://doi.org/10.20473/ijosh.v5il. 2016.51-60

9. Kumroni Makmuri, Amiluddin Zahri, W. A. (2018). Analisis Kursi Sopir dan Kernet Truk Ekspedisi Darat Menggunakan Metode Macroergonomic Analysis adn Design (MEAD). Seminar Nasional Dan Kongres Perhimpunan Erbonomi Indonesia (PEI) Ke VIII, ED-79(8), 1-15.

http://weekly.cnbnews.com/news/article.ht $\mathrm{ml} ? \mathrm{no}=124000$

10. Szóstak, M. (2019). Analysis of occupational accidents in the construction industry with regards to selected time parameters. Open Engineering, 9(1), 312320. https://doi.org/10.1515/eng-2019-0027

How to cite this article: Trianto $\mathrm{AB}$, Muh. Yusuf, Muh. Rifai. Factor analysis related to truck mixer driver work accident at PT Bosowa Beton Indonesia. International Journal of Science \& Healthcare Research. 2021; 6(3): 7987. DOI: https://doi.org/10.52403/ijshr. 20210714 